\title{
A Prospective Evaluation of Missed Injuries in Trauma Patients, Before and After Formalising the Trauma Tertiary Survey
}

\author{
Gerben B. Keijzers • Don Campbell • Jeffrey Hooper • \\ Nerolie Bost · Julia Crilly • Michael Craig Steele • \\ Chris Del Mar • Leo M. G. Geeraedts Jr.
}

Published online: 1 October 2013

(C) The Author(s) 2013. This article is published with open access at Springerlink.com

\begin{abstract}
Objective This study prospectively evaluated in-hospital and postdischarge missed injury rates in admitted trauma patients, before and after the formalisation of a trauma tertiary survey (TTS) procedure.

Methods Prospective before-and-after cohort study. TTS were formalised in a single regional level II trauma hospital in November 2009. All multitrauma patients admitted between March-October 2009 (preformalisation of TTS) and December 2009-September 2010 (post-) were assessed
\end{abstract}

Presented at the International Conference for Emergency Medicine, Dublin, Ireland, June 27-30, 2012.

G. B. Keijzers $(\varangle) \cdot$ D. Campbell $\cdot$ J. Hooper · N. Bost Emergency Department, Gold Coast Health Service District, Gold Coast University Hospital, 1 Hospital Boulevard,

Southport, QLD 4215, Australia

e-mail: gerben_keijzers@health.qld.gov.au

D. Campbell

e-mail: Don_Campbell@health.qld.gov.au

J. Hooper

e-mail: Jeffrey_Hooper@health.qld.gov.au

N. Bost

e-mail: Nerolie_Bost@health.qld.gov.au

\section{G. B. Keijzers}

School of Medicine, Bond University, Gold Coast, QLD,

Australia

G. B. Keijzers

School of Medicine, Griffith University, Gold Coast, QLD,

Australia

J. Crilly

Statewide Emergency Department Clinical Network, Gold Coast

University Hospital, 1 Hospital Boulevard, Southport,

QLD 4215, Australia

e-mail: Julia_Crilly@health.qld.gov.au for missed injury, classified into three types: Type I, in-hospital, (injury missed at initial assessment, detected within $24 \mathrm{~h}$ ); Type II, in-hospital (detected in hospital after $24 \mathrm{~h}$, missed at initial assessment and by TTS); Type III, postdischarge (detected after hospital discharge). Secondary outcome measures included TTS performance rates and functional outcomes at 1 and 6 months.

Results A total of 487 trauma patients were included (pre-: $n=235$; post-: $n=252$ ). In-hospital missed injury rate (Types I and II combined) was similar for both groups (3.8 vs. $4.8 \%, P=0.61$ ), as were postdischarge missed injury rates (Type III) at 1 month (13.7 vs. $11.5 \%$, $P=0.43)$, and 6 months (3.8 vs. $3.3 \%, P=0.84)$ after

J. Crilly

Research Centre for Clinical and Community Practice Innovation, Griffith University, PO Box 7057, Gold Coast, QLD 4222, Australia

M. C. Steele

Faculty of Business, Bond University, Gold Coast, QLD, Australia

e-mail: misteele@bond.edu.au

M. C. Steele

Griffith Graduate Research School, Griffith University, Gold Coast, QLD, Australia

C. Del Mar

Public Health, School of Medicine, Bond University,

Gold Coast, QLD, Australia

e-mail: cdelmar@bond.edu.au

L. M. G. Geeraedts Jr.

Department of Surgery, VU University Medical Centre, PO Box 7057, 1007 MB Amsterdam, The Netherlands e-mail: 1.geeraedts@vumc.nl 
discharge. TTS performance was substantially higher in the post-group ( 27 vs. $42 \%, P<0.001)$. Functional outcomes for both cohorts were similar at 1 and 6 months follow-up. Conclusions This is the first study to evaluate missed injury rates after hospital discharge and demonstrated cumulative missed injury rates $>15 \%$. Some of these injuries were clinically relevant. Although TTS performance was significantly improved by formalising the process (from 27 to $42 \%$ ), this did not decrease missed injury rates.

\section{Introduction}

A common quality indicator in trauma care is missed injury $[1,2]$. Missed injuries are the result of the prioritisation that takes place during the initial assessment and management in the emergency department (ED) and emergency intervention. Because the focus in the $\mathrm{ED}$ is on making timecritical decisions, complete injury identification during resuscitation (including primary and secondary survey) is not always feasible [3-5].

Performance of a trauma tertiary survey (TTS) within $24 \mathrm{~h}$ has been suggested as a tool to address this problem and minimise the risk of missed injuries [3]. The TTS should follow the episode of emergency care (primary and secondary survey and emergency interventions). It comprises a comprehensive general physical reexamination and review of all investigations, including diagnostic imaging and blood results, within $24 \mathrm{~h} \mathrm{[4-6]} \mathrm{and} \mathrm{again} \mathrm{when} \mathrm{the}$ patient is conscious, cooperative, and mobilised [3, 6, 7].

The TTS would be expected to reduce missed injuries and therefore improve trauma care. However, our recent

Box 1 Missed injury classification [8]

\begin{tabular}{|c|c|}
\hline $\begin{array}{l}\text { Missed injury } \\
\text { type }\end{array}$ & Description \\
\hline I & $\begin{array}{l}\text { Before TTS, or as result of TTS-in-hospital } \\
\text { Injury missed at initial assessment (primary and } \\
\text { secondary survey and emergency intervention), but } \\
\text { detected within } 24 \mathrm{~h} \text {, before or through formal } \\
\text { TTS (delayed diagnosis at } 24 \text { h). (i.e., injury } \\
\text { missed at initial assessment) }\end{array}$ \\
\hline II & $\begin{array}{l}\text { After TTS, in-hospital } \\
\text { Injury missed by TTS, detected in hospital after } \\
24 \text { h (i.e., injury missed at initial assessment and } \\
\text { TTS) }\end{array}$ \\
\hline III & $\begin{array}{l}\text { After TTS, after hospital discharge } \\
\text { Injury missed during hospital stay including TTS, } \\
\text { detected after hospital discharge (i.e., injury } \\
\text { missed at initial assessment and TTS and hospital } \\
\text { stay) }\end{array}$ \\
\hline
\end{tabular}

TTS tertiary trauma survey systematic review [8] found the evidence to support this is suboptimal. Among the deficiencies was the substantial variation in outcome definitions for missed injury (leading to a recommendation for a classification focused on consistent outcome definitions, as outlined in Box 1). None reported missed injury rates after hospital discharge (Type III) nor functional (long-term) outcomes [3, 5, 7, 9-13].

A retrospective study [14] in our facility found poor compliance to routine TTS and identified a lack of data regarding postdischarge missed injuries. As a result, we pragmatically evaluated prospectively the missed injury rates during hospital stay (Types I and II) as well as after discharge (Type III) in trauma patients in our level II facility, before and after implementation of a formalised TTS procedure.

\section{Materials and methods}

\section{Design and setting}

A prospective cohort study with before-and-after design was conducted on trauma patients who were admitted to the Gold Coast Hospital between March 2009 and October 2010. The Gold Coast Hospital is a public teaching hospital and is the designated, level II [15], regional trauma hospital for the area and covers all major specialties, excluding cardiac surgery and burns. The ED had 67,000 presentations in 2010, and the hospital had no dedicated trauma service or formalised process for review of admitted trauma patients. Patients were managed at the discretion of the admitting consultant and team. The Human Research Ethics Committees of the Gold Coast Health Service District and Bond University approved the study.

Patients

All admitted multitrauma patients were identified prospectively. Patients eligible for study inclusion were aged 16 years and older and admitted for at least $24 \mathrm{~h}$, AND met any of the four following criteria: (1) injuries in two or more body regions, (2) a high impact mechanism (highspeed motor vehicle collision, pedestrian versus car, fall from $>1.5$ meter), (3) chest or abdominal injuries, or (4) diagnosed with a fractured neck of femur younger than aged 65 years. These inclusion criteria were based on previous work [14]. Patients were identified using the Emergency Department Information System (EDIS) and the hospital based corporate information system (HBCIS). The resultant database was complemented with data from the Queensland Trauma Registry (QTR). All patients or their proxies were asked to provide written consent for a 1and 6-month telephone follow-up interview. 


\section{Implementation of practice change (formalised TTS- intervention)}

During a 3-week period in November 2009, a hospital-wide practice change was implemented via a formalised TTS procedure. Implementation involved (i) the provision of TTS forms (Appendix 1) to trauma admitting wards, (ii) repeated education for all levels of medical and nursing staff working on these wards on the use of the TTS form, and (iii) a directive from the surgical departmental head for TTS form completion as part of routine care within $24 \mathrm{~h}$ of admission.

Before the implementation of the formalised TTS (preintervention period, March 2009 to 3 November 2009) routine care was provided at the discretion of the admitting team. The treating team performed TTS at their discretion, based on their clinical judgment and without standardised forms. Trauma admitting teams provided the same care following the practice change (postintervention period, 28 November 2009 to September 2010) except for the use the formalised and standardised TTS form. Data collection procedures were identical in both time periods.

\section{Data collection}

We prospectively identified eligible patients and reviewed their medical records. A previously used data collection tool (Appendix 2) was used to assess the documentation of the relevant admission [15]. Data collected by the trained research nurse included demographic variables, mechanism of injury, Australasian Triage Scale category (ATS) [16], and Glasgow Coma Scale (GCS) on arrival. If no GCS was documented, but the patient was noted to be "alert," this was coded as a GCS of 15. The QTR provided the Injury Severity Score (ISS) [17] scores for our dataset. An ISS score of greater than 15 indicated severe trauma.

Data related to the inpatient admission included whether a TTS was documented during admission and which components of the TTS were performed. A scripted followup telephone interview (Appendix 3) was conducted at 1 and 6 months after discharge. This follow-up interview collected data on missed injuries after discharge, complications of care, return to preinjury function, and ongoing medical care requirements. If not contactable during initial phone call, up to five attempts were made by the research nurse at varying times and days for both the 1- and the 6-month follow-up interviews.

If patients indicated during follow-up that an injury was missed during their hospital stay, this prompted review of relevant medical records and imaging reports by a consultant emergency physician, who determined whether this was a true missed injury. An injury was only classified as "missed injury" if there was no documentation (in either medical record or radiology report) of the reported injury during the hospital stay. Musculoskeletal injuries included fractures and lacerations where soft-tissue injuries were defined as other musculoskeletal injuries, such as contusions, grazes and haematomas that caused pain, swelling, or lack of function. The emergency physician also could classify the reported "injury" as a complication of the injury (i.e., paresthesia, chronic pain) or complication of care (such as postoperative infection or venous thromboembolism). Patients who reported a missed injury were offered appropriate pathways for follow-up. Finally, a search of the Death Registry (Queensland Registry for Births, Deaths and Marriages) was undertaken to identify the mortality rate at 6 months posthospital discharge and cause of death.

The primary outcome was missed injury rate. Three types of missed injuries have been defined previously [8] and are shown in Box 1. This study prospectively evaluated the in-hospital missed injury rate (Types I and II combined) and postdischarge missed injury rate (Type III) before and after the implementation of a formalised TTS. Secondary outcome measures included TTS performance rates and functional outcomes at 1 and 6 months posthospital discharge.

Sample size and statistical analysis

We anticipated an overall missed injury rate (Types I, II, and III combined) of $15 \%$ in the pre-period and expected the formalised TTS to reduce the missed injury rate to $5 \%$. Using an alpha of 0.05 and a power of 0.8 , a sample size of 110 per group was required. Because we anticipated a telephone follow-up rate of $45 \%$, a total of 244 patients was required for both cohorts.

Before analysis, the accuracy of patient inclusion and demographic data were checked with the QTR database. Discordant data fields $(<5 \%)$ were reviewed and corrected. Deidentified data was analysed using SPSS v17.0 software (SPPS Inc., Chicago, IL). For continuous variables, we used an independent $t$ test and analysis of variance (ANOVA) to compare demographic groups. For categorical variables, the Chi square test was used to compare differences in proportions. A $P$ value $\leq 0.05$ was deemed statistically significant.

This study is reported to adhere to the STROBE statement (www.strobe-statement.org).

\section{Results}

The baseline characteristics of the pre- and post-practice change cohorts ( $n=235$ and $n=252$, respectively) are summarised in Table 1 . The cohorts are comparable in 
Table 1 Characteristics of the study population

\begin{tabular}{lll}
\hline Characteristics & $\begin{array}{l}\text { Preintervention, } \\
n=235\end{array}$ & $\begin{array}{l}\text { Postintervention, } \\
n=252\end{array}$ \\
\hline Age, year mean (SD) & $40.4(17)$ & $41.1(19)$ \\
Male, $n(\%)$ & $169(72)$ & $194(79)$ \\
ISS score, median (IQR) & $9(12)$ & $10(12)$ \\
ISS $>15, n(\%)$ & $56(24)$ & $61(26)$ \\
GCS $<15, n(\%)$ & $54(23)$ & $50(20)$ \\
Mechanism of Injury & & \\
MVA, high speed, $n(\%)$ & $25(11)$ & $15(6)$ \\
MVA, moderate speed, $n(\%)$ & $26(11)$ & $36(14)$ \\
MBA, $n(\%)$ & $41(17)$ & $47(19)$ \\
Fall from height $>1.5$ metres, & $49(21)$ & $62(25)$ \\
$n(\%)$ & & $11(4)$ \\
Pedestrian vs. car, $n(\%)$ & $16(7)$ & $82(32)$ \\
Other blunt mechanism, $n(\%)$ & $78(33)$ & $89(35)$ \\
Disposition from ED & & $76(30)$ \\
Surgical ward, $n(\%)$, & $88(37)$ & $84(33)^{*}$ \\
Orthopedic ward, $n(\%)$ & $77(33)$ & $4(2)^{*}$ \\
ICU, $n(\%)$ & $56(24)$ & $13(6)$
\end{tabular}

$S D$ standard deviation, $I Q R$ interquartile range, ISS injury severity score, GCS Glasgow coma scale, $M V A$ motor vehicle accident, $M B A$ motor bike accident, $E D$ emergency department, $I C U$ intensive care unit

$* P<0.05$

demographics, such as age, gender, and injury severity, although a higher percentage of patients in the post-cohort was admitted to the intensive care unit (ICU): 24 vs. $33 \%$, $P=0.02$. Mortality was not significantly different (2.6 vs. $1.2 \%, P=0.26$; Table 2).

Missed injuries in-hospital (Types I and II combined)

The rate of combined Types I and II (in-hospital) missed injuries was similar for both cohorts (pre-: $3.8 \%$ vs. post-: $4.8 \%, P=0.61$; Tables 2, 3).

Missed injuries postdischarge (Type III)—at 1 and 6 months

Patients in the both pre- and post-cohorts reported similar rates of missed injuries during follow-up telephone interview at 1 month (13.7 vs. $11.5 \%, P=0.59)$ and 6 months (3.8 vs. $3.3 \%, P=0.84$; Table 3 ). Complication rates also were similar for both cohorts at 1 and 6 months (Table 3 ). Most injuries were musculoskeletal or soft-tissue in nature. Of the soft-tissue injuries, four required intervention (ligamentous cervical spine injury required a neck brace, two knee injuries required surgery for cruciate ligament injury,
Table 2 Trauma tertiary survey and missed injuries

\begin{tabular}{lll}
\hline $\begin{array}{l}\text { TTS elements and missed } \\
\text { injuries }\end{array}$ & $\begin{array}{l}\text { Preintervention, } \\
n=235\end{array}$ & $\begin{array}{l}\text { Postintervention, } \\
n=252\end{array}$ \\
\hline $\begin{array}{l}\text { TTS performed, } n(\%) \\
\text { Major components of TTS, } \\
n(\%)\end{array}$ & $65(27)$ & $106(42)^{* * *}$ \\
C-spine & $26(40)$ & $60(57)^{*}$ \\
Chest & $32(49)$ & $100(94)^{* * *}$ \\
Abdomen & $49(75)$ & $100(94)^{* * *}$ \\
Pelvis & $10(15)$ & $57(54)^{* * *}$ \\
Back & $4(6)$ & $53(50)^{* * *}$ \\
Missed injuries & & \\
Type I and II (combined) & & $12 / 252(4.8)$ \\
$\quad$ Detected in-hospital, $n /$ & $9 / 235(3.8)$ & \\
$N(\%)$ & & $14 / 122(11.5)$ \\
Type III & & $3 / 92(3.3)$ \\
Detected post hospital & & $3(1.2)$ \\
discharge & & \\
At 1 month, $n / N(\%)$ & $18 / 131(13.7)$ \\
At 6 months, $n / N(\%)$ & $4 / 105(3.8)$ & $6(2.6)$ \\
Mortality, $n(\%)$ & & \\
\hline
\end{tabular}

TTS trauma tertiary survey, $n$ number of events, $N$ population at follow-up

* $P<0.05 ; * * P<0.01 ; * * * P<0.001$

and one shoulder injury required surgery for rotator cuff injury).

TTS performance

The implementation of a formalised TTS on trauma admitting wards substantially improved TTS performance (pre- $27 \%$ vs. post- $42 \%, P<0.001$ ). All major components of reexamination were significantly more frequently performed in the post-cohort (Table 2).

Missed injuries by TTS performance

Both in pre- and post-cohorts, more injuries were detected in-hospital (Types I and II) when a TTS was performed compared with when this was not done (pre- $6 / 65=9.2 \%$ vs. $3 / 170=1.8 \%, P=0.008$; post- $10 / 106=9.4 \%$ vs. $2 / 145=1.4 \%, P=0.003)$.

There was no difference in Type III injury detection at 1 month and 6 months between patients who received a formal TTS compared with those who did not in either the pre- cohort $(1$ month $5 / 28=17.9 \%$ vs. $13 / 103=12.6 \%$, $P=0.54 ; \quad 6$ months $2 / 23=8.7 \%$ vs. $2 / 82=2.5 \%$, $P=0.21)$ or post-cohort (1 month $4 / 41=9.8 \%$ vs. $10 / 81=12.3 \%, P=0.77 ; 6$ months $1 / 28=3.6 \%$ vs. $2 / 64=3.1 \%, P=1.00)$. 
Table 3 Type and time of missed injuries and complications detected $n$ number of events, $N$ total population, \# fracture, STI softtissue injury, $D V T$ deep vein thrombosis, PE pulmonary embolism, PTSD posttraumatic stress disorder, $C$ conservatively managed, $R$ referral to specialist, $I$ surgical intervention required

\begin{tabular}{|c|c|c|}
\hline $\begin{array}{l}\text { Missed injury (type and time) and } \\
\text { complication }\end{array}$ & Preintervention, $n / N(\%)$ & Postintervention, $n / N(\%)$ \\
\hline $\begin{array}{l}\text { Types I and II (combined)—detected in- } \\
\text { hospital }\end{array}$ & $\begin{array}{l}9 / 235 \text { patients }(3.8 \%) \\
\text { Total injuries }=11 \\
(9 \times \mathrm{C}, 3 \times \mathrm{R}, 2 \times \mathrm{I}) \\
1 \times \text { finger } \#(\mathrm{C}) \\
1 \times \text { facial } \#(\mathrm{R}, \mathrm{I}) \\
1 \times \text { sternum \# }(\mathrm{C}) \\
1 \times \text { calcaneum \# }(\mathrm{R}, \mathrm{C}) \\
1 \times \text { hearing loss }(\mathrm{R}, \mathrm{C}) \\
6 \times \mathrm{STI}(5 \times \mathrm{C}, 1 \times \mathrm{I})\end{array}$ & $\begin{array}{l}12 / 252 \text { patients }(4.8 \%) \\
\text { Total injuries }=18 \\
(15 \times \mathrm{C}, 5 \times \mathrm{R}, 3 \times \mathrm{I}) \\
2 \times \text { lacerations }(2 \times \mathrm{I}) \\
1 \times \text { tibia plateau } \#(\mathrm{R}, \mathrm{I}) \\
1 \times \text { ankle } \#(\mathrm{R}, \mathrm{C}) \\
3 \times \text { abdominal pain }(3 \times \mathrm{R}, \\
3 \mathrm{xC}) \\
11 \times \mathrm{STI}(11 \times \mathrm{C})\end{array}$ \\
\hline $\begin{array}{l}\text { Type III—detected at } 1 \text { month after } \\
\text { discharge }\end{array}$ & $\begin{array}{l}18 / 131 \text { patients }(13.7 \%) \\
(15 \times \mathrm{C}, 5 \times \mathrm{R}, 3 \times \mathrm{I}) \\
13 \times \mathrm{STI}(12 \times \mathrm{C}, 1 \times \mathrm{I}) \\
2 \times \text { scaphoid } \#(2 \times \mathrm{R}, \\
2 \times \mathrm{C}) \\
1 \times \text { mandible } \#(\mathrm{R}, \mathrm{I}) \\
1 \times \text { dislocated toes }(\mathrm{R}, \mathrm{I}) \\
1 \times \text { laceration scalp }(\mathrm{R}, \mathrm{C})\end{array}$ & $\begin{array}{l}14 / 122 \text { patients }(11.5 \%) \\
(12 \times \mathrm{C}, 2 \times \mathrm{R}, 2 \times \mathrm{I}) \\
1 \times \text { distal radius } \#(\mathrm{R}, \mathrm{C}) \\
1 \times \mathrm{L} 4 \#(\mathrm{R}, \mathrm{C}) \\
12 \times \mathrm{STI}(10 \times \mathrm{C}, 2 \times \mathrm{I})\end{array}$ \\
\hline $\begin{array}{l}\text { Type III-detected at } 6 \text { months after } \\
\text { discharge }\end{array}$ & $\begin{array}{l}4 / 105 \text { patients }(3.7 \%) \\
(4 \times \mathrm{C}, 2 \times \mathrm{R}) \\
1 \times \text { ulnar styloid } \#(\mathrm{R}, \mathrm{C}) \\
1 \times \text { visual loss }(\mathrm{R}, \mathrm{C}) \\
2 \times \text { STI }(2 \times \mathrm{C})\end{array}$ & $\begin{array}{l}3 / 93 \text { patients }(3.3 \%) \\
(2 \times \mathrm{C}, 3 \times \mathrm{R}, 1 \times \mathrm{I}) \\
1 \times \text { patella } \#(\mathrm{R}, \mathrm{C}) \\
1 \times \text { rib } \#(\mathrm{R}, \mathrm{C}) \\
1 \times \text { tooth } \#(\mathrm{R}, \mathrm{I})\end{array}$ \\
\hline \multicolumn{3}{|l|}{ Complications } \\
\hline Reported at 1 month & $\begin{array}{l}11 / 131(8.4 \%) \\
5 \times \mathrm{DVT} \\
1 \times \mathrm{PE} / \text { arrest } \\
3 \times \text { headache/dizzy } \\
2 \times \text { infection }\end{array}$ & $\begin{array}{l}\text { 10/122 }(8.2 \%) \\
1 \times \mathrm{DVT} \\
1 \times \mathrm{PE} \\
4 \times \text { paresthesia } \\
4 \times \text { infection }\end{array}$ \\
\hline Reported at 6 months & $\begin{array}{l}7 / 105(6.7 \%) \\
1 \times \text { DVT } \\
3 \times \text { chronic pain } \\
1 \times \text { vertigo } \\
1 \times \text { PTSD } \\
1 \times \text { seizures }\end{array}$ & $\begin{array}{l}8 / 92(8.7 \%) \\
1 \times \text { DVT } \\
2 \times \text { chronic pain } \\
3 \times \text { STI } \\
1 \times \text { paresthesia } \\
1 \times \text { infection }\end{array}$ \\
\hline
\end{tabular}

Functional outcomes-at 1 and 6 months

The proportion of patients returning to almost normal or normal level of functioning was similar for both cohorts at 1 month (pre- $20 \%$ vs. post- $17 \%, P=0.61$ ) and 6 months (pre- $39 \%$ vs. post- $44 \%, P=0.53$; Tables 4 , $5)$. Of the patients who returned to work or university, there was no difference in average hours worked at 1 month (pre- $31 \mathrm{~h}$ vs. post- $34 \mathrm{~h}, P=0.29$ ) and 6 months (pre- $39 \mathrm{~h}$ vs. post- $36 \mathrm{~h}, P=0.22$ ). Both cohorts had similar proportions of ongoing follow-up, mainly general practitioner (GP), physiotherapy, and occupational therapy.

\section{Discussion}

We did not find a difference in missed injury rates (inhospital and after discharge) as a result of the implementation of a formalised TTS procedure. However, this study is the first to report on missed injuries after hospital discharge (Type III) related to TTS performance in the multitrauma population. We found a substantial cumulative missed injury rate 1 and 6 months after hospital discharge. Approximately 1 in 6 (between 15 and $18 \%$ ) of the patients who were available for follow-up reported Type III missed injuries, either at 1 or 6 months. Of these patients with Type III missed injuries $(n=39$ in both cohorts 
Table 4 1-month functional outcomes

\begin{tabular}{|c|c|c|}
\hline 1 month outcomes & $\begin{array}{l}\text { Preintervention, } \\
n=132\end{array}$ & $\begin{array}{l}\text { Postintervention, } \\
n=122\end{array}$ \\
\hline \multicolumn{3}{|l|}{$\begin{array}{l}\text { Returned to prelevel } \\
\text { functioning in }\end{array}$} \\
\hline \multicolumn{3}{|l|}{$\mathrm{ADL}, n(\%)$} \\
\hline Yes & $8(6)$ & $4(3)$ \\
\hline Almost & $18(14)$ & $17(14)$ \\
\hline Difficulty with some ADL & $38(29)$ & $34(28)$ \\
\hline Difficulty with most ADL & $64(49)$ & $64(53)$ \\
\hline Unable & $3(2)$ & $3(3)$ \\
\hline \multicolumn{3}{|l|}{ Hours at work, mean h (SD) } \\
\hline Preinjury, $n=106, n=91$ & $39(15)$ & $43(11)$ \\
\hline $\begin{array}{l}1 \text { month post injury, } n=41 \text {, } \\
n=28\end{array}$ & $31(14)$ & $34(10)$ \\
\hline \multicolumn{3}{|l|}{ Ongoing follow-up } \\
\hline GP & $85(64)$ & $71(59)$ \\
\hline Physiotherapist & $40(30)$ & $36(30)$ \\
\hline OT & $15(11)$ & $18(15)$ \\
\hline (Community) nurse & $17(13)$ & $5(4)^{*}$ \\
\hline Psychologist & $3(2)$ & $3(3)$ \\
\hline
\end{tabular}

$A D L$ activities of daily living, $S D$ standard deviation, $G P$ general practitioner, $O T$ occupational therapist

$* P<0.05$

Table 5 6-month functional outcomes

\begin{tabular}{lll}
\hline 6-month outcomes & $\begin{array}{l}\text { Preintervention, } \\
n=105\end{array}$ & $\begin{array}{l}\text { Postintervention, } \\
n=92\end{array}$ \\
\hline $\begin{array}{l}\text { Returned to prelevel } \\
\text { functioning in } \\
\text { ADL, } n \text { (\%) } \\
\text { Yes }\end{array}$ & \\
Almost & $20(19)$ & $21(23)$ \\
Difficulty with some ADL & $21(20)$ & $19(21)$ \\
Difficulty with most ADL & $27(26)$ & $29(32)$ \\
Unable & $1(1)$ & $12(25)$ \\
Hours at work, mean h (SD) & & \\
Preinjury, $n=90, n=74$ & $40(13)$ & $41(12)$ \\
6-month post injury, $n=64$, & $39(14)$ & $36(13)$ \\
$n=57$ & & \\
Ongoing follow-up & & $46(50)$ \\
GP & $47(45)$ & $43(47)$ \\
Physiotherapist & $58(55)$ & $10(11)$ \\
OT & $13(12)$ & $7(8)$ \\
(Community) nurse & $10(10)$ & $7(8)$ \\
Psychologist & $6(6)$ & \\
\hline PL activities & &
\end{tabular}

$A D L$ activities of daily living, $S D$ standard deviation, $G P$ general practitioner, $O T$ occupational therapist

$* P<0.05$ combined), almost one-third $(n=12)$ required a specialist referral, and $13 \%$ of these $(n=5)$ required surgical intervention. Furthermore, this is the first study that reports on functional outcomes and ongoing health care consumption related to the TTS. We did not find any differences in measured outcomes.

The in-hospital (Types I and II) missed injury rate (pre$3.8 \%$ vs. post- $4.8 \%$ ) was consistent with previous literature, including a retrospective review in the same hospital (in-hospital missed injury rate of $3.3 \%$ ) and a systematic review $[8,15]$ reporting an average in-hospital missed injury rate of $4.3 \%$.

The (Type III) postdischarge missed injury rate reported by patients at 1 - and 6-month follow-up was three- to fourfold higher than our in-hospital missed injury rate. Potential explanations for this finding include, but are not limited to: (1) serial physical examination or TTS were not performed or incomplete; (2) abnormal physical examination or radiology findings were incorrectly interpreted (misdiagnosis); (3) abnormal findings were diagnosed, but not documented.

We did not find an overall effect of formalising the TTS, with similar missed injury rates and functional outcomes in both cohorts. Despite the significant increase in TTS performance, this practice improvement may not have been enough to have an effect on missed injury rates. Whilst we implemented measures to optimise TTS performance (e.g., involving key stakeholders and providing repeated education sessions), the compliance of the TTS was still not performed in more than half of the patients. This may be explained by the pragmatic, real-world nature of this study and possible reasons include: lack of (institutional) governance regarding trauma care, staff turnover, perceived loss of autonomy, high clinical workload, external pressures and difficulties in achieving a (cultural) change in behaviour-a problem not unique to our study [18-20].

Although we did not find a difference between the two cohorts, the analysis of missed injury rate by TTS performance suggests that any form of TTS, either routine (pre-) or formal (post-), increases in-hospital missed injury detection (Types I and II) but has little effect on injuries post postdischarge (Type III). Because this was not part of the original hypothesis and this comparison is potentially flawed due to possible selection bias, this data should be interpreted with caution.

\section{Limitations}

The limited success of changing practice from routine non-standardised TTS to the formalised TTS forms procedure is likely due to the pragmatic nature of this study however there are some further limitations. First, this is a 
single-site study, which may limit the ability to generalise the results. However, the in-hospital missed injury rate is consistent with the existing literature, suggesting the practice in our institution is not likely to be markedly different from others. Second, as we were unable to identify a validated published instrument that measured the postdischarge outcomes of interest, we created our own scripted telephone interview. Functional outcomes we measured included: return to preinjury level of activities, hours worked, as well as the requirement to have further medical or allied health involvement after hospital discharge. Further validation of these post discharge outcomes in this population is recommended. Third, the follow-up rates at $1(\sim 50 \%)$ and 6 months $(\sim 40 \%)$ may have introduced selection bias. Although our telephone response rates compare favourably to other studies [20,21], patients who were unable to be interviewed may have had similar or more missed injuries. In the unlikely situation that none of the patients lost to follow up had a missed injury, the overall postdischarge (Type III) missed injury rate would still be considerable at $8 \%$ (39/487). Fourth, we relied on self-report of new injuries during the telephone interviews, but this is unlikely to have lead to systematic error between the two cohorts. We were unable to determine the accuracy of self-reporting of complications such as chronic pain and DVT. Furthermore, there was a large proportion of patients with musculoskeletal and soft-tissue injuries. This is consistent with the literature [8]. Although soft-tissue injury was the final diagnosis, clinical review and/or diagnostic imaging often was required. Although the majority of patients did not require intervention, some patients still had delayed recovery as a result. Lastly, although we accessed the Queensland Death registry, we cannot rule out that patients died in other states or countries.

\section{Conclusions}

This is the first study to describe missed injury rates after hospital discharge in relation to TTS performance. However, attempting to improve tertiary survey rates by pragmatically formalising the process did not have a significant effect on (in-hospital-Types I and II, or postdischarge-Type III) missed injury rates. We attribute this to the real-world nature of this study with sub-optimal increase in TTS performance (from 27 to $42 \%$ ) as a result of this practice change.

The focus of the literature up to date has been on in-hospital missed injuries (Type I and Type II) and this is the first study report on post-discharge missed injuries (Type III), with several requiring consultant referral and surgical intervention. A simple checklist (such as a standardised TTS form) may not be enough, and a multifaceted, system approach may be required to address the problem of patients returning to the community with undiagnosed injuries. One solution may be improved governance, for example by implementation of a dedicated trauma service.

Acknowledgments Chris Heenan from the Gold Coast Hospital for data collection and The Queensland Trauma Registry for their support and data. This study received funding from the Queensland Emergency Medicine Research Foundation (QEMRF-EMSS-2008-008). No industry or pharmaceutical funding was received. The funding body had no involvement in study design, data collection, analysis, or interpretation of the data.

Conflict of interest There are no conflicts of interest.

Open Access This article is distributed under the terms of the Creative Commons Attribution License which permits any use, distribution, and reproduction in any medium, provided the original author(s) and the source are credited.

\section{Appendix 1}




\section{$\underline{\text { Data Collection sheet - Tertiary Survey Study }}$}

Patient UR:

(Place pt sticker here)

Consent for telephone follow up

\section{$\square$ Yes}

$\square$ No

$\square$ Not possible yet

Please check contact details on sticker above (alternative phone numbers):

1.

2.

Confirm best times to contact:

1.

2.

Date of tertiary survey

\section{DEMOGRAPHICS}

1. Date of admission:

2. Date of discharge (if known):

3. Age: years

4.Gender

$\square$ Male

$\square$ Female

\section{Triage Category (in ED)}

$\square 1$

ㅁ 2

ㅁ 3

ㅁ 4

$\square 5$

\section{Mechanism of trauma}

口 MVA- high Speed (>100 km/hr/ rollover/ejection)

$\square$ MVA - moderate speed, no rollover/ejection)

$\square$ MBA

$\square$ Fall from height $>1$ meter or 5 steps

$\square$ Pedestrian vs car

$\square$ Other

\section{GCS (on arrival in ED):}

\section{8. (Initial) Disposition}

$\square$ Surgical ward

$\square$ Orthopedic ward

$\square$ Intensive Care Unit (ICU)

$\square$ Observation Ward

$\square$ Operating Theatre (OT)

$\square$ other:

\section{Tertiary Survey at 24 hours}

9. On which admission day has tertiary survey been completed?

$\square$ within 24 hours of admission

$\square$ between 24-48 hours of admission

$\square>48$ hours

$\square$ No tertiary survey documented

10. Who has performed the tertiary survey?

$\square$ Not performed

$\square$ Intern

$\square \mathrm{JHO} / \mathrm{SHO}$

$\square$ Registrar

$\square$ Consultant

$\square$ Unknown/Unclear

11. Who has documented the tertiary survey?

$\square$ Not performed

$\square$ Intern

$\square \mathrm{JHO} / \mathrm{SHO}$

$\square$ Registrar

$\square$ Consultant

$\square$ Unknown/Unclear

With regards to the documentation of the tertiary survey, have the following components been documented in the chart?

Examination

- Current Vital signs documented?:

12. Glasgow Coma Scale (GCS)

$\square$ Yes

$\square$ No

13. Temperature

$\square$ Yes

$\square$ No

14. Blood Pressure

$\square$ Yes

$\square$ No

15. Heart Rate

$\square$ Yes

$\square$ No

16. Respiratory Rate

$\square$ Yes

$\square$ No

17. Oxygen Saturation

$\square$ Yes

$\square$ No

-- Physical Examination documented?

-- Head and face

18. Scalp

$\square$ Yes

$\square$ No

19. Face

$\square$ Yes

$\square$ No 


\section{Eyes (including visual acuity) \\ $\square$ Yes \\ $\square$ No \\ 21. Ears \\ $\square$ Yes \\ $\square$ No \\ 22. Mouth \\ $\square$ Yes \\ $\square$ No \\ 23. Cranial Nerves \\ $\square$ Yes \\ $\square$ No \\ -- Neck and C-spine}

\section{Neck}

$\square$ Yes

$\square$ No

25. Trachea

$\square$ Yes

$\square$ No

26. C-spine (cleared + documented)

$\square$ Yes

$\square$ No

-- Chest

27. Chest Wall (incl Ribs)

$\square$ Yes

$\square$ No

28. Sternum (incl Ribs)

$\square$ Yes

$\square$ No

29. Clavicle/Shoulder

$\square$ Yes

$\square$ No

30. ICC (if present)

$\square$ Yes

$\square$ No

N/A

-- Abdomen \& pelvis

31. Abdomen

$\square$ Yes

№

32. Pelvis

$\square$ Yes

$\square$ No

33. Genitalia

$\square$ Yes

$\square$ No

-- Back

34. General Back

$\square$ Yes

$\square$ No

35. T-spine and L-spine

$\square$ Yes

$\square$ No
-- Extremities

36. Upper Limbs

$\square$ Yes

$\square$ No

37. Lower Limbs

$\square$ Yes

$\square$ No

38. Pulses

$\square$ Yes

$\square$ No

-- Pathology(documented?)

39. Full Blood Count

$\square$ Yes

$\square$ No

40. Coagulation studies

$\square$ Yes

$\square$ No

41. UELFTs

$\square$ Yes

$\square$ No

42. Blood transfusion (documented)

$\square$ Yes

$\square$ No

43. Plain Radiology (plain films) review documented?

$\square$ Yes

$\square$ No

44. Who has reviewed Plain Radiology (plain films)?

$\square$ Intern

a $\mathrm{JHO} / \mathrm{SHO}$

$\square$ Registrar

व Consultant

口 Radiology registrar

$\square$ Radiology consultant

$\square$ N/A

45. Advanced Radiology (CT, USS, MRI) review documented?

$\square$ Yes

$\square$ Partially

$\square$ No

46. Who has reviewed Advanced Radiology (CT, USS, MRI)?

$\square$ Intern

口 JHO/SHO

$\square$ Registrar

$\square$ Consultant

口 Radiology registrar

$\square$ Radiology consultant

$\square$ N/A

47. Are there newly detected injuries as a result of the tertiary survey?

$\square$ Yes

$\square$ No

$\square$ 48. if answered yes to Q47 please specify:

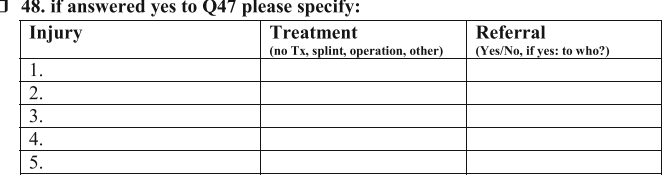

49. Injury Summary documented?

$\square$ Yes

$\square$ No 


\section{Appendix 2}

Evaluating the Implementation of a Tertiary Survey for Admitted Trauma Patients

Patient Study Code: $\square 1$ month post discharge Date of interview:

$\square$ month post discharge

Introduce yourself, where you are calling from and ask to speak to the participant themselves if aged 18 years or older or the parent of the study participant (if aged $<18$ years).

If they are not available to come to the phone say:

"Could you please let me know when might be a more convenient time to call back?"

\section{If asked what it is about say:}

"Name (participant) was admitted to the Gold Coast Hospital about 6 months ago. We phoned a month after discharge to ask questions about how things had gone. During that interview they agreed to be called one final time at 6 months after discharge. Are they available for five to ten minutes, please?"

If the participant declines to be interviewed, say:

"Well we hope everything related to your hospital visit went well and that your health is OK now. Thank you for your previous help. Good bye"

\section{DEMOGRAPHICS (to cross check with chart)}

$\begin{array}{lll}\text { Who completed interview? } & \text { Gender } & \text { Age (at time of admission) } \\ \square \text { Participant } & \square \text { Male } & \\ \square \text { Parent/Caregiver } & \square \text { Female } & \text {..........years }\end{array}$

\section{Appendix 3}

\section{INTERVIEW}

Thanks for your time again. Since our last interview, we would like to ask a few questions regarding your recovery after the injuries you sustained that required you to be admitted to the Gold Coast Hospital 6 months ago.

1. To start off, can you please list if any new injuries were detected after our first interview 1 month after discharged:

2. Since our last interview 1 month after discharge, have you required further medical review for the injuries you sustained?

$\square \quad$ Yes

$\square \quad$ No

If answered $\boldsymbol{Y E S}$, did you... (can tick more than one)

$\square \quad$ Yes - saw GP

$\square \quad$ Yes - re-present to ED

ㅁ Yes - readmitted to hospital

$\square \quad$ Yes - other

The next few questions are about how you were functioning PHYSICALLY before your recent injury that required hospital admission.

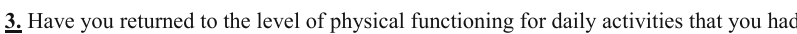
before your injury?

$\square$
$\square \quad$ Yes, completely
$\square$

$\square \quad$ No, difficulty with some activities

$\square \quad$ No, difficulty with most activities

$\square \quad$ No, Unable to function at all

4a. If answered $Y E S$... What do you put this down to? (prompt via open question)

Injuries were minor

ㄱ Good Physiotherapy/Rehabilitation

a Good pain relief

O Other and detail below

4b. If answered $N O \ldots$ What do you put this down to (prompt via open question)? Injuries are severe/likely permanent Ongoing physio/rehabilitation need

Nerve/muscle damage

In plaster cast

Other and detail below

5. Before the injury, did you go to:

$\begin{array}{ll}\square & \text { School } \\ \square & \text { University } \\ \square & \text { Work }\end{array}$

5a. If working, approximately how many hours each week did you work? hours/week

5b. After your injury are you now back at:

\begin{tabular}{llll}
\multicolumn{2}{l}{ School } & \multicolumn{3}{l}{ University } \\
$\square$ & YES & $\square$ & YES \\
$\square$ & NO & $\square$ & NO \\
$\square$ & N/A & $\square$ & N/A \\
Work & & & \\
$\square$ & YES & Other & \\
$\square$ & NO & $\square$ & YES \\
$\square$ & N/A & $\square$ & NO \\
$\square$ & & $\square$ & N/A
\end{tabular}

5c. If working, Now, approximately how many hours each week do you work?

hours/week 


\section{References}

1. Gruen RL, Gabbe BJ, Stelfox HT et al (2012) Indicators of the quality of trauma care and the performance of trauma systems. $\mathrm{Br}$ J Surg 99(Suppl 1):97-104

2. Stelfox HT, Straus SE, Nathens A et al (2011) Evidence for quality indicators to evaluate adult trauma care: a systematic review. Crit Care Med 39:846-859

3. Enderson BL, Reath DB, Meadors J et al (1990) The tertiary trauma survey: a prospective study of missed injury. J Trauma 30:666-670

4. Biffl WL, Harrington DT, Cioffi WG (2003) Implementation of a tertiary trauma survey decreases missed injuries. J Trauma 54:38-44

5. Vles WJ, Veen EJ, Roukema JA et al (2003) Consequences of delayed diagnoses in trauma patients: a prospective study. J Am Coll Surg 197:596-602

6. Janjua KJ, Sugrue M, Deane SA (1998) Prospective evaluation of early missed injuries and the role of tertiary trauma survey. J Trauma 44:1000-1007

7. Soundappan SV, Holland AJ, Cass DT (2004) Role of an extended tertiary survey in detecting missed injuries in children. J Trauma 57:114-118

8. Keijzers GB, Giannakopolous GF, Del Mar C et al (2012) The effect of tertiary surveys on missed injuries in trauma: a systematic review. Scand J Trauma Resusc Emerg Med 20:77. doi:10.1186/1757-7241-20-77

9. Ursic C, Curtis K, Zou Y et al (2007) Improved trauma patient outcomes after implementation of a dedicated trauma admitting service. Injury 38:112-117

10. Hoff WS, Sicoutris CP, Lee SY et al (2004) Formalised radiology rounds: the final component of the tertiary survey. J Trauma 56: 291-295

11. Huynh TT, Blackburn AH, McMiddleton-Nyatui D et al (2010) An initiative by midlevel providers to conduct tertiary surveys at a level I trauma center. J Trauma 68:1052-1058

12. Okello CR, Ezati IA, Gakwaya AM (2007) Missed injuries: a Ugandan experience. Injury 38:112-117
13. Howard J, Sundararajan R, Thomas SG et al (2006) Reducing missed injuries at a level II trauma center. J Trauma Nurs 13: 89-95

14. Keijzers GB, Campbell D, Hooper J et al (2011) Tertiary survey performance in a regional trauma hospital without a dedicated trauma service. World J Surg 35:2341-2347. doi:10.1007/ s00268-011-1231-3

15. The Australian Trauma Verification Program Manual. Royal Australasian College of Surgeons (2009). http://www.surgeons. org/media/309244/2009-08-04_Trauma_Verification_Manual.pdf. Accessed 6 Sept 2012

16. Australasian College of Emergency Medicine Policy on Australian Triage scale (2012). http://www.acem.org.au/media/ policies_and_guidelines/P06_Aust_Triage_Scale_-_Nov_2000.pdf. Accessed 6 Sept 2012

17. Baker SP, O’Neill B, Haddon W Jr et al (1974) The injury severity score: a method for describing patients with multiple injuries and evaluating emergency care. J Trauma 14:187-196

18. Bennetts S, Campbell-Brophy E, Huckson S, National Health and Medical Research Council's National Institute for Clinical Studies National Emergency Care Pain Management Initiative et al (2012) Pain management in Australian emergency departments: current practice, enablers, barriers and future directions. Emerg Med Australas 24:136-143

19. Eskicioglu C, Gagliardi AR, Fenech DS et al (2012) Surgical site infection prevention: a survey to identify the gap between evidence and practice in University of Toronto teaching hospitals. Can J Surg 55:233-238

20. Keijzers G, Crilly J, Walters B, Crawford R et al (2010) Does a dedicated pediatric team within a busy mixed emergency department make a difference in waiting times, satisfaction and care transition? Pediatric Emerg Care 26:274-280

21. Hall J, Jelinek GA (2007) Characteristics and outcomes of patients who leave without being seen after attending Perth public hospital emergency departments, 2000-2003. Med J Aust 187: $626-629$ 